\title{
Women's Writing of The First World War
}

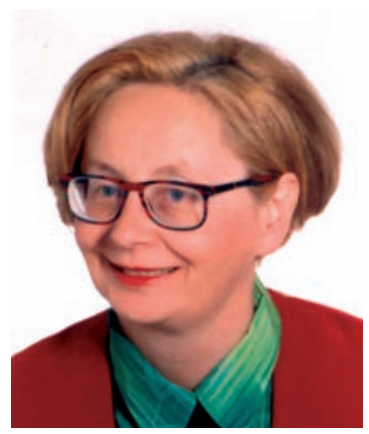

Aleksandra Kedzierska

\section{Pierrot Goes to War}

In a sheltered garden, pale beneath the moon, (Drenched with swaying fragrance, redolent of June!)

There, among the shadows, some one lingers yetPierrot, the lover, parts from Pierrette.

Bugles, bugles, bugles, blaring down the wind, Sound the flaming challenge - Leave your dreams behind! Come away from shadows, turn your back on JunePierrot, go forward to face the golden noon!

In the muddy trenches, black and torn and still, (How the charge swept over, to break against the hill!) Huddled in the shadows, boyish figures lie They whom Death, saluting, called upon to die.

Bugles, ghostly bugles, whispering down the wing Dreams too soon are over, gardens left behind. Only shadows linger, for love does not forget Pierrot goes forward - but what of Pierrette?

(Gabrielle Elliot)

$\mathrm{I}^{\mathrm{n}}$ ner introduction to Scars Upon my Heart', an anthology of Women's Poetry and Verse of the First World War, Catherine Reilly notes that she "succeeded in identifying no fewer than 2225 British individuals ..., servicemen and civilians, who had written verse on the theme of this most terrible war" (1981, xxxiii). Although, as she hastens to add, over five hundred of these (532 to be exact) were women, their works unlike those of soldier poets' - could rarely be found in the mainstream war anthologies of the last century. After a somewhat grudging admittance into the collections of war poems of the 1960s, reserved at first to the chosen few: Charlotte $\mathrm{Mew}^{2}$, Fredegond Shove and later to Alice Maynell, the remaining voices had to wait longer still to be finally rescued from oblivion. Even nowadays, despite the fact that "a more representative showing is made by women war poets", ${ }^{3}$ and that their works found way to such important collections of the last decades as (Hibberd D. and Onions J. Poetry of the First World War. Basingstoke and London: Macmillan, 1986; Stephen's M. Never Such Innocence gain: a New Anthology of Great War Verse. London: J M Dent, 1993; Roberts' D. Minds at War. Sussex: Saxon Books, 1996) there still, as Michele Fry claims, "remains a great deal to be done if women war poets are to be accorded the place that many critics feel they deserve in the canon of English poetry of the First World War". ${ }^{4}$ 
Although unlike their men, the women poets of 1914-18 were usually confined to the Home Front, they too, and in more ways than one, were exposed to the harsh reality of the war in which they could hardly afford to remain uninvolved in the struggle against the common enemy. Some, after all, made it to the Front; others did what they could in order to be of some help to their heroes in the trenches. Who knows, perhaps in comparison with too familiar to all of us Bosch, the women's enemy was even worse, for in addition to their everyday cares they had to confront an overwhelming sense of loss of all those not destined to return home. Or even more tragically, the alienation of the survivors - those who did come back but only as mutilated wrecks, or mental cases and who then, like perhaps never before, relied and depended on their women for love.

England honoured her sons with numerous memorials, the Remembrance Day, and with the cult of the trench poems which, published and republished, were also being extensively discussed. However, the sacrifice of her daughters has remained largely unrecognized, regardless of the extent of their involvement in the Home Front activities. Thus, Pierrette, the woman who in the unique poem by Gabrielle Elliot epitomized all others left behind when their Pierrots went to war and, over the top, was once again betrayed and pushed back into the tradition-sanctified insignificance. Hence, drawing on the works compiled in Reilly's seminal anthology, this essay will concern itself with the fate of the Great War Pierrettes, demonstrating that, like the soldier poets elsewhere, "the war girls" on the Home Front were also fighting for the truth of war, revealing its pity, its horror and its glory in the places only rarely described by men: in the family home, hospital wards or the country's numerous factories.

Being but a fragment of a greater whole, this presentation will concentrate on that aspect of the Home Front reality which, covered by the poetry and fiction inspired by the years 1914-18, best characterizes the women as fighters - the soldiers of the new they turned into by embracing their chance of employment in factories which were springing up round England to satisfy the demands of the war.

"The departure of many thousands of men from their traditional roles, and their replacement by women, added to the general psychology of confusion which the war introduced to society. Nothing was permanent any more, nothing predictable. Many of the rules of gender around which the society had been constructed were being bent and broken. Women chose, or were forced, in many instances for the first time, to leave their homes and enter the world of men, and it was bound to offer them a very different taste of life" (Smith 4). However, when, especially "[a]fter the introduction of conscription in March 1916, the government encouraged women to take the place of the male employees who have been released from their normal occupations to serve at the Front", 5 thousands of them responded with the enthusiasm comparable to that with which their men had been waiting to enlist, grateful, almost like the soldiers in the celebrated sonnet by R. Brooke ("Peace"), that God "matched them with this hour". Now they too were getting ready to plunge into the promise of new life, which meant an uprooting - and a collapse in the case of domestic service - of traditional women's employment ${ }^{6}$, and though the offer was most heartily welcome by working class women, through them the life of middle and upper class homes was affected. Even Archie, a little boy from Nina 
Macdonald's poem, "Sing a Song of War-Time", notices that

Mummy does the house-work,

Can't get any maid,

Gone to make munitions,

'Cause they're better paid,

Nurse is always busy,

Never time to play,

Sewing shirts for soldiers,

Nearly ev'ry day. (SMH 69)

After a solemn afternoon spent "waving good bye" to the soldiers sent off to the Front, the boy resignedly accepts his "tea" which consists of only bread and margarine. Miserable, he recites the catalogue of his woes, those most acutely felt, including lack of money for toys and no decent dessert ("cake or any sort of jam") that would make up for his loneliness. When the big boys were losing their battles overseas, little ones like Archie, no longer the center of the women's world, seemed to be losing theirs at home, where left to themselves they soon learned their lessons in "war economy":

Ev'ry body's doing

Something for the War,

Girls are doing things

They've never done before,

Go as 'bus conductors.

Drive a car or van,

All the world is topsy-turvy

Since the war began. (SMH 69)

The image of the world gone "topsy-turvy" well renders the revolutionary character of changes in women's employment and the extent of their effort in support of the war. This effort is further documented by one of the most famous and controversial poets of the Great War, Jessie Pope ${ }^{7}$ whose "War Girls" seems to both chronicle and celebrate the female exodus out of the confinement of tradition. Like Brooke's warriors, finally "awakened from sleeping," with "hand made sure, clear eye, and sharpened power," they were to welcome that road to independence, financial and otherwise, which would so often lead - even in the case of the middle class women through employment.

There's the girl who clips your ticket for the train, And the girl who speeds the lift from floor to floor, There's the girl who does a milk-round in the rain, And the girl who calls orders at your door.

Strong, sensible, and fit,

They are out to show their grit, 
And tackle jobs with energy and knack.

No longer caged and penned up,

They're going to keep their end up

Till the khaki soldier boys come marching back.

There's the motor girl who drives a heavy van,

There's the butcher girl who brings your joint of meat,

There's the girl who cries 'All fares, please!', like a man,

And the girl who whistles taxis up the street.

Beneath each uniform

Beats a heart that's soft and warm,

Though of canny mother-wit they show no lack;

But a solemn statement this is,

They've no time for love and kisses

Till the khaki soldier boys come marching back. (SMH 90)

This time an adult speaker registers an explosion of energy translating itself into a variety of activities, all of which done by the women who, "no longer caged and penned up", are now "out to show their grit" and "tackle jobs with energy and knack", determined to succeed and to "keep the end up / Till the khaki soldier boys come marching back". Strength becomes a visible attribute of the war girls, this air of authority enhanced by the uniforms they wear as well as by the ease with which they perform what only a short time ago used to be exclusively male roles. Interestingly, some have adopted much more than just men's garb - whistling taxis up the street or crying "All fares, please!"- they have already started behaving like men. The speaker, however, refuses to be taken in by this somewhat masculinized image of working girl, explaining that this display of toughness, which by no means stifles her femininity, will end as soon as "the soldier khaki boys come marching back". One has but to penetrate the fazade of the uniform to find that beneath each there beats a soft and warm woman's heart, generous enough - when the nation needs it - to sacrifice her "love and kisses". Constituting the borderline between their private and public selves, the uniform - highly desirable and proudly worn - becomes a sartorial symbol of the expansion of space women successfully appropriated having left nurseries and kitchens.

From among the many jobs opening up to satisfy the demands of war, women would frequently choose work in munitions, their experiences there finding way into such poems as, for instance, Madeline Ida Bedford's "Munition Wages" and Mary Gabrielle Collins's "Women at Munition Making". Given the specificity of the job, not only most directly connected with the Front experience but resembling it in the organization and harshness of work (shift system) as well as women's constant exposure to injury and death, work in munitions was believed to be patriotic if only because it "provided a further bond with men serving at the front". ${ }^{8}$ However, the true reason for the job's popularity with "Tommy's sisters", as munitionettes were also called, was the possibility to earn even as much as "fifty bob a week", which on average was five times more than a woman would get as her pre-war pay. And then, as M. Rushton claims, apart 
from this financial incentive, there were also other attractions, for instance "a six-bed hospital and a dentist on site and a canteen for meal breaks offering a two-course meal for $10 \mathrm{~d}$. a day, [and] shopping facilities that saved precious time otherwise spent in a queue".

In spite of such obvious "perks", working in munitions was "a touch and go biz", where one had to be always on alert to Zeppelin attacks and to the danger of explosion while handling TNT. Bad ventilation, ill fitting and scarce protective gear, yet above all women's direct exposure to chemical substances and explosives could not but affect their health. Soon "war wenches" would complain of irritant chest pains, nausea, and eating or/and menstruation disorders which would eventually lead even to infertility. However, the most noticeable health problem came from TNT poisoning which turned the women's hair green and their skin yellow: this peculiar colouring earned munitionettes the name of the "canary girls". Many (around 400) ${ }^{10}$ died from overexposure to TNT or from other kinds of chemical substance poisoning; many lost their lives in explosions, the biggest of them - "Britain's worst ever disaster" (134 workers killed and 250 injured) which took place in Chilwell, Nottingham in July 1918." And then there was depression, often caused by the drudgery of work accompanied by prison-like discipline. "Work shifts of 10-12 hours were not uncommon," Goldstein writes, adding that "conditions in factories were, for women, an 'alien environment' of deafening noise and depressing grime, encased by blacked-out windows". ${ }^{12}$ In her novel, We That Were Young (1932), Irene Rathbone describes the condition of Staple and Studd's munition works at Willesden: "Two hundred and fifty girls divided into sections according to the different jobs they were doing; three hundred men in other parts of the same vast shed. From eight to five, with an hour's break for lunch, they work unceasingly" (qtd. from Smith 308). Some sat at the drilling machines, surrounded by broad leather belts which, suspended from the ceiling, would incessantly flap and whirr. "The noise made by all the belts together was like a flock of nightmare birds. Added to it was the noise of the drilling of the plates; and from all parts of the shop came a mixed din of rasping, filing, cutting, hammering. Clang, clang, zzz, whrr. Clang, clang, zzz, whrr. Clang, clang, zzz, whrr. Deafening, stupefying, brain-shattering” (qtd. from Smith 308-9).

Interestingly, regardless of all these dangers and discomforts, "the factory was advertised as a 'gay' workplace (in the old sense of the word) for workers", ${ }^{13}$ and many women claimed they did enjoy their work there. And yet, apart from the money earned - and it must be noted that "the women received nowhere near fortunes they had been led to expect when deciding to take war work" - most often "the woman war worker had little in her life now except work and sleep". ${ }^{14}$

Hence, the uniqueness of Bedford's poem "Munition Wages", glorifying the new life style of one of "Tommy's sisters". Her monologue communicates the working class woman's delight in getting "five quid a week", and in her thus earned independence allowing her to taste the pleasures she could barely dream about before. She takes time to provide many details of her improved status which, by creating an optimistic version of the Home Front (not just its employment), seems to suggest her acceptance of the war 
if only for its contribution into producing this species nova: a working class girl who can act like a lady and who for once "ain't living bad". Boasting to her male interlocutor that she, "a woman, too", can have "high wages", she basks in the sense of equality between them generated by employment, proud of her new life. The munitionette's main satisfaction is earning money and spending "the whole racket" to the last penny. Saving, she makes clear, does not suit her hedonistic pursuits. Years back, the woman recalls, she wore "tatters", now "silk stockings". To her "war economy" is a miracle which has brought not only liberation but also many material possessions:

I've bracelets and jewelry,

Rings envied by friends;

A sergeant to swank with,

And something to lend.

I drive out in taxis,

Do theatres in style.

And this is mi verdict -

It is jolly worth while. (SMH 7)

Although the girl neither mentions the drudgery of work nor criticizes the working conditions, her optimism is not completely 'fear-proof'. Every now and then, as if momentarily forgetting her bravado, she shows her awareness of the darker side of this "dim sweet" war paradise. "See "ere", she explains to her companion:

\author{
it's \\ $\cdots$ \\ A touch-and-go biz. \\ We're all here today, mate, \\ Tomorrow - perhaps dead, \\ If Fate tumbles upon us \\ And blows up our shed. (SMH 7)
}

And yet, as she goes on to add, she is by no means afraid, not with "money to spend!" No wonder that exuding a sense of power and strength, protected by her money and a "sergeant to swank with", the munitionette is concerned with her own death mainly in economic terms. "If [tomorrow] I'm blown to the sky", she says, "I'll have repaid my wages/ In death - and pass by" (SMH 8). Even Jessie Pope would find it difficult to locate a soft, patriotic heart in this war girl, which seems to merely confirm Goldstein's observation that "contrary to popular belief (...) the main motivation [of munitions workers] was [not] patriotic". ${ }^{15}$ The myth of 'gay work' is further undermined by Mary Gabrielle Collins's depiction of "Women at Munition Making". There, a better educated and obviously middle-class speaker, capable of seeing through the economic euphoria of high wages, reveals the work's devastating impact upon the girls' humanity. Juxtaposing 
the traditional image of woman in peace time with that of war wenches, the poem laments the erosion of many essential attributes of their femininity. The munitionettes hardly resemble "angels of the house" characterized by softness, tenderness, and patience. Irrevocably gone is also the thrill of motherhood with its symbol of "rosy teat swelling with milk". Instead, the hands that used to and should "minister unto the flame of life" are now busy assembling gun components or filling shells and cartridges, "taking part in defacing and destroying the natural body" which, they understand, "[i]s the shrine of the spirit".

This transformation into the priestesses of death brings about the women's physical degradation visible in the coarsening of their hands and fingers. Still worse, however, is the impact the work has upon munitionettes' psyche. Though created to dwell "among the sweetest mind flowers", the women's thoughts - now "bruised against the law" - find their only nourishment in the imperative of "kill, kill," the word repeated twice as if to erase even the vaguest memory of the fifth commandment (thou shalt not kill).

Thus their employment, often indicative of their preference of career over family, keeps turning against them - also through shattering their God-given vocation and the ideals it used to define. Besides, burdening them with a greater sense of responsibility and guilt, it merely adds to a woman's negative image of herself.

Emerging towards the close of the poem, this image reveals that, by supporting man in his war effort and becoming an accomplice in his crimes, the woman has acquired his worst characteristics. And yet, by attacking God Himself, her involvement carries the men's "canceling" of each other and their" annihilation of God's work one step further. Stressing the desecrating character of the women's work in munitions, the speaker realizes that it

Taints the fountain head,

Mounts like a poison to the Creator's very heart.

O God!

Must it anew be sacrificed on earth? (SMH 24)

Having stopped marveling at how things happened, and taken to co-creating them, women who "taint" the most sacred "fountain head" of life can no longer be viewed as its symbol; the only fruit they now seem capable of bearing is a new cross they fashion while making munitions. Paradoxically, these modern crucifiers are themselves victimized, becoming helpless witnesses of their own disintegration, bewildered that the hand, the fingers to which they have been reduced (see 11. 1-2) can eagerly launch their attack against "God's very heart", the challenge whose sense evades their understanding.

Though filtered through time, the importance of munitionettes' experience as part of the truth of the Great War is also reflected in Pat Barker's Regeneration (trilogy, 199395) which completes the portrayal of Bedford's and Collins's war girls by depicting the one finally capable of offering the reader a far more profound and hence invaluable insight into the harsh reality of munitions. Sarah Lumb is one of the "canary girls" from Scarborough, a typical working class woman who, having left domestic service, has found a much more reliable and better paid job in munitions, and who can really enjoy 
the work which allows her to feel more distinguished and brings her both substantial income and the independence she desires. Yet, even though she candidly speaks to her soldier boyfriend of her earnings, she realizes that this chance of regeneration has indeed been bought for a high price. She herself is a living proof that the work literally "gets under her skin", affecting her physiology and her appearance, her yellowed complexion automatically betraying her as a sufferer from TNT ailment.

Besides, even Sarah, figuratively speaking, is not immune against the depressing monotony of the job, whose specific, apparently meaningless tasks have to be repeated again and again during twelve-hour shifts, six days a week, the drudgery of detonators production made still worse by the women having to work in silence, each sitting by her small worktable, separated from others by a dim circle of light. During the day, with guards and controls everywhere, the munitions resemble some huge top security prison, yet one's sense of entrapment is even more overpowering at night when the red flames raging in the factory furnaces give the place a hellish look. Sometimes, when working the night shifts, especially when the familiar faces and figures disappear beneath the shapeless overalls and unbecoming caps and masks the workers have to wear, Sara experiences a strange sense of unreality and seeing herself reflected in other women, she concludes: "we do not resemble human beings (...) we look like machines producing other machines". ${ }^{16}$

Sara's boyfriend went to war and he did not even have to go over the top; he was killed by mistake by the British troops. Just as for many other Pierrettes left behind, work in munitions meant a new start in life, a chance to do something with and for herself; also for others for whom they often risked their health and life. Today we know that this work, precious as it then seemed to be, was hardly what the Canaan women had hoped to get. Already in 1918, when the 'khaki boys' returned from the trenches, they wanted their jobs back and their women at home. And many quickly forgot how much, involved in the Home Front and Overseas activities, women had done for their country. Hence Vera Brittain's "Lament for the Demobilized":

"Four years', some say consolingly. 'Oh well,

What's that? You're young. And then it must have been

A very fine experience for you!'

And they forget

How others stayed behind and just got on -

Got on the better since we were away.

And we came home and found

They had achieved, and men revered their names,

But never mentioned ours;

And no one talked heroics now, and we

Must just go back and start again once more.

'You threw four years into the melting-pot-

Did you indeed!' these others cry. 'Oh well,

The more fool you!'

And we're beginning to agree with them. (SMH 14) 
It is such voices that are still hoping to be heard, for then perhaps somebody will say 'thank you'. By presenting this mixture of fiction and verse, it has become possible to "reclaim the Great War as an arena of female experience, and to rediscover some of the written material which articulates that experience" (Smith 1) thus proving that although "history has gendered the War as male", there still exists an equally fascinating and for some even a more "representative impression of the Great War as it was lived, worked, and fought by women, who are so often excluded from official versions" (Smith 9).

\section{Notes and References:}

1. Scars Upon My Heart. Women's Poetry and Verse of the First World War. / (ed.) Catherine Reilly. With a Preface by Judith Kazantzis. London: Virago Press Ltd., 1981. All quotations of poetry come from this edition (abbreviated in the text as $\mathrm{SMH}$ ), with page number specified in brackets. Reilly makes clear that at least 417 men and women served in the armed forces or other uniformed organizations such as the Red Cross, the 'Special Constabulary, and the Voluntary Aid Detachment.

2. See Maurice Hussey (ed.). Poetry of the First World War. An Anthology. London: Longmans, Green and Co. Ltd., 1967. Hussey publishes poems by Alice Meynell; two works by Charlotte Mew and Fredegond Shove were placed in: Ian Parsons (ed.). Men Who March Away. London : Chatto and Windus, 1965.

3. Fry Michele. Counter-Attack: Defining the Canon of English Poetry of the First World War. www. sassoonerv. demon. co. uk/vvw1 canon. Htm\#top. 5.01.2005.

4. Fry Michele. Counter-Attack: Defining the Canon of English Poetry of the First World War. www.sassoonerv.demon.co.uk/ww1 canon.htm\#top. 5.01.2005.

5. Bourke Joanna. Women and Employment on the Home Front During World War One. www.bbc.co.uk/historv/war/wwone/women_emplovment_01.sthml. 2201 2005. See also Bourke's "Women and the Military during World War One". http ://www.bbc.co.uk/historv/war/wwone/womencombatants01.sthml. 22012005.

6. Smith A.K. writes. "For many middle class women the War provided the opportunity to become involved in a completely different world as they took on a variety of jobs, all voluntary and unpaid which were deemed appropriate for respectable young ladies. The reality was often a far cry from appropriate, and they... came face to face with horrors of the battlefield as Voluntary Aid Detachment (VAD) nurses in hospitals and as ambulance drivers in the First Aid Nursing Yeomanry (FANY). (34). "For working class women", Smith continues, "the common course of action was to take over from their husbands when they enlisted. Others filled vacancies left by men in public service, industries, on trams and buses, or working on the land" (4). Besides, there were numerous other possibilities of war jobs for women who could find work assembling and sandpapering gun components, operating drilling equipment, excavating, plumbing; they worked as air mechanics, in forestry and in glass factories, and breweries, as cooks in infantry camps, in naval ship building, commerce, clerical jobs, organizing war support, providing food and other supplies 
to the military, telephone operators (Hallo Girls), entertainers (singers, dancers, companions, poetry readers, lecturers) messengers, porters, lift operators, bus conductors, bank clerks, shop attendants, bookkeepers, etc.

7. Pope Jessie was one of the most popular and patriotic women poets of the Great War, whose works are often taught in opposition to "the ideas of the major war poets such as Owen or Sassoon". See MacCallum E. Jessie Pope.

http://www.whatalovelywar.co.uk/jessiehtm. 17.01.2005. According to SMH, Jessie Pope "contributed some 200 poems and articles to Punch, wrote humorous fiction, verse and articles for leading popular magazines and newspapers. (SMH, 136).

8. Caddick-Adams Peter. The Home Front, BBC- History Trail- Wars and Conflict. http://www.bbc.co.uk/cgi-bin/historv/renderplain.pl?file=/history/. p.4, 22012005.

9. Rushton Maureen. The Canary Girls of Chilwell. http://www.nottsfhs.org.uk/society/joumals/apr01.htm. p.2, 5022005.

10. Caddick-Adams Peter. The Home Front, BBC - History Trail - Wars and Conflict. http://www.bbc.co.uk/cgi-bin/history/renderpiain.pl?file=/history/. p.4,22 012005.

11. Rushton Maureen. BBC Inside Out - Chilwell Blast Tragedy. http://www.bbc.co.uk./insideout/eastmidlands/series2/blastchilweH.htm, p.2,22 0105

12. Goldstein Joshua S. The Women of World War I. http://www.wargender.com/wgwomwwi.htm. p.8, 02282005.

13. Rushton Maureen. The Canary Girls of Chilwell. http://www.nottsfhs.org.uk/society/journals/apr01.htm. p.4, 02012005.

14. Goldstein Joshua S. The Women of World War I. http://www.wargender.com/wgwomwwi.htm. p.8, 02282005.

15. Ibid.

16. This quotation from P. Barker's Regeneration comes from an article by Karin Westman: Pat Barker's Regeneration - Critical Contexts - Munitionettes. http://www.ksu.edu/english/westmank/regeneration/munitionettes.harris.html 25.01.05.

\section{WORKS CITED:}

1. Bourke Joanna. Women and the Military during World War One. http://www.bbc.co.uk/historv/war/wwone/women_combatants_01.sthml, 22012005.

2. Bourke Joanna. Women and Employment on the Home Front During World War One. www.bbc.co.uk/history/war/wwone/women_employment_01.sthml, 22012005.

3. Caddick-Adams Peter. The Home Front, BBC - History Trail - Wars and Conflict. http://www.bbc.co.uk/cgi-bin/history/renderplain.pl?file=/history/, 22012005.

4. Fry Michele. Counter-Attack: Defining the Canon of English Poetry of the First World War. www.sassoonery.demon.co.uk/ww1 canon.htm\#top, 5.01.2005.

5. Goldstein Joshua S. The Women of World War I. 
http://www.wargender.eom/wgwomwwi.htm, p. 8, 02282005.

6. Hussey Maurice (ed.). Poetry of the First World War. An Anthology, London, Longmans, Green and Co. Ltd, 1967.

7. Parsons Ian (ed.). Men Who March Away, Chatto and Windus. London, 1965.

8. Scars Upon My Heart. Women's Poetry and Verse of the First World War. Catherine Reilly (ed.). With a Preface by Judith Kazantzis. London: Virago Press Ltd., 1981.

9. Rushton Maureen. The Canary Girls of Chilwell. http://www.nottsfhs.org.uk/society/journals/apr01.htm, p. 2, 220105.

10. Rushton Maureen. BBC Inside Out - Chilwell Blast Tragedy.

http://www.bbc.co.uk./insideout/eastmidlands/series2/blast_chilwell.htm. p.2, 220105

11. Smith Angela K. (ed.). Women's Writing of the First World War. Manchester and New York: Manchester University Press, 2000.

12. Westman Karin. Pat Barker's Regeneration - Critical Contexts - Munitionettes. http://www.ksu.edu/english/westmank/regeneration/munitionettes.harris.html, 25.01.2005.

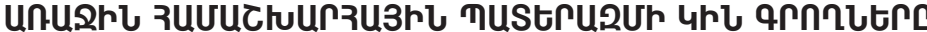

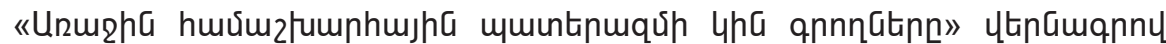

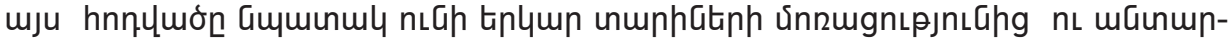

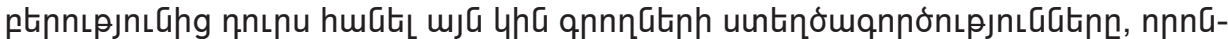

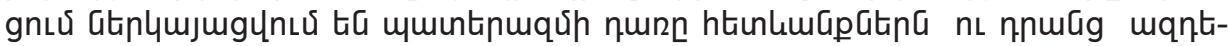
gnıpjnıGn luaGuGig पnm:

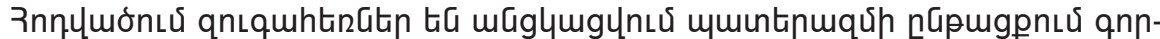

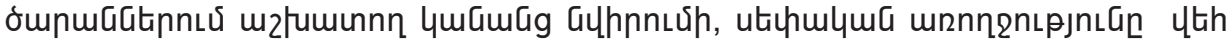

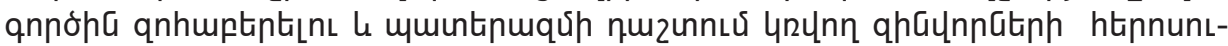

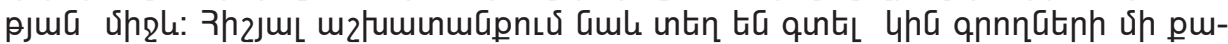

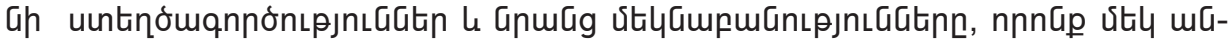

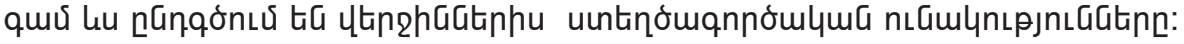

